\title{
SENP1/MESDC2 Fusion Protein
}

National Cancer Institute

\section{Source}

National Cancer Institute. SENP1/MESDC2 Fusion Protein. NCI Thesaurus. Code C99842.

A fusion protein encoded by the SENP1/MESDC2 fusion gene. This protein is comprised of the extreme $\mathrm{N}$-terminus of the sentrin-specific protease 1 protein fused to all but the first 71 or 106 amino acids of the LDLR chaperone MESD protein. 